\title{
The Existences of International Law in The Establishment of Indonesian National Regulation on The Protection of Traditional Knowledge
}

\author{
Budi Hermawan Bangun ${ }^{1}$ \\ ${ }^{1}$ Faculty of Law, Universitas Tanjungpura, budi.h.bangun79@gmail.com
}

\begin{abstract}
Introduction to The Problem: The debate about whether the protection of traditional knowledge governed by international law has led developing countries, such as Indonesia, to have the potential for traditional knowledge to feel disadvantaged.

Purpose/Objective Study: This paper intends to discuss the existence of international law in the formation of Indonesian national regulations concerning the protection of traditional knowledge.

Design/Methodology/Approach: This research designed as doctrinal legal research. The data used in this study are secondary data which analyzed qualitatively Findings: From the results of research and discussion it is known that stipulation of regulations related to the protection of traditional knowledge in Indonesia needs to be accompanied by efforts to encourage the acceptance of national interests in international agreements, both through increasing TRIP agreements and the ASEAN framework. Also, it must be ensured that all binding international legal instruments related to traditional knowledge will truly benefit especially the community of traditional knowledge owners in Indonesia.
\end{abstract}

Paper Type: Research Article

Keywords: International Law; National Regulation; Traditional Knowledge Protection

\section{Introduction}

In the last few decades, the concept of Intellectual Property Rights (IPR) protection has continued to experience significant progress. The IPR protection primarily contained in the Trade-Related Aspects of Intellectual Property Rights (TRIP's), which is an annex of the Marrakech Agreement of 1995 on the establishment of the World Trade Organization (WTO) that provides individualistic and specific protection over a while (Oguamanam, 2004).

One development that is still a heated debate in the context of IPR is related to traditional knowledge. Traditional knowledge is a knowledge developed by indigenous communities or intellectual works based on tradition (Hawin, 2009). In the Convention on Biological Diversity, traditional knowledge defined as (Hawin, 2009): 
"Traditional knowledge refers to the knowledge, innovations, and practices of indigenous and local communities around the world. Developed from experience gained over the centuries and adapted to the local culture and environment, traditional knowledge is transmitted orally from generation to generation. It tends to be collectively owned and takes the form of stories, songs, folklore, proverbs, cultural values, beliefs, rituals, community laws, the local language, and agricultural practices, including the development of plant species and animal breeds. Traditional knowledge is mainly of a practical nature, particularly in such fields as agriculture, fisheries, health, horticulture, and forestry."

Meanwhile, WIPO (World Intellectual Property Organization) freely defines traditional knowledge as (The Secretariat of WIPO, 2002):

"tradition-based literary, artistic or scientific works; performances; inventions; scientific discoveries; designs; marks, names, and symbols; undisclosed information; and all other tradition-based innovations and creations are resulting from intellectual activity in the industrial, scientific, literary, or artistic fields.".

The definition of traditional knowledge linking it with indigenous peoples/communities contains complexity because they may be the owners of traditional knowledge, but not always all the owners of traditional knowledge are indigenous peoples/communities (Oseitutu, 2013). Nevertheless, traditional knowledge has a unique characteristic as a knowledge gained as a result of interaction with nature, practiced on a genetic basis, and the ownership of that knowledge is communal.

In practice, traditional knowledge always intersects with genetic resources as well as traditional cultural expression (folklore). Genetic resources are materials derived from plants, animals, microbes, or other genetic resources that have potential value to develop, whereas traditional cultural expressions are a culture born from a community group and have been passed down from generation to generation, such as dances.

This distinctive characteristic of traditional knowledge sparked debate because there is the unregulated type of IPR, such as traditional knowledge in the TRIP's framework. According to Xiong (2008), there are at least two obstacles in aligning traditional knowledge with IPR regimes, namely: public domain and disclosure of information. The nature of traditional knowledge, which is a shared knowledge of a community and a cultural inclination that does not record in writing, makes difficulties for traditional knowledge to gain protection in the IPR regimes.

This debate occurs mainly between developing states and developed states with different perspectives on protecting traditional knowledge. The difference between the views of the two societies lies in the basic concepts and aspects of ownership. The basic concept of capitalist-individual western society sees traditional knowledge as a 
property that can be individually owned, whereas local or traditional societies view it more as cultural heritage or cultural expression (Rosidawati, 2013).

As a result of the debate, there has been no international agreement on whether or not traditional knowledge is protected by international law. On the other hand, the developing states, including Indonesia, which have much potential traditional knowledge feel disadvantaged about the frequent occurrence of misappropriation or use by foreigners who are ignoring the rights of local communities to the traditional knowledge and associated biological resources which belong to the community concerned (Sardjono, 2010).

In the context of Indonesia, with all its potential related to traditional knowledge, Indonesia to date has not had any specific national regulation related to the protection of traditional knowledge. Even though Indonesia has ratified Nagoya Protocol and also regulates the distribution of results and access to utilization of traditional knowledge in Article 26 of Act No. 13 of 2016 on Patent, but this is inadequate. It makes the interests of local communities in Indonesia relatively unprotected because their traditional knowledge can be exploited by others for commercial purposes under the pretext that there are no regulations against it. In consequence, there is a need to make a regulation that regulates explicitly traditional knowledge.

Indonesia's national regulation related to IPR such as Act No. 28 of 2014 on Copyright; Act No. 13 of 2016 on Patent; Act No. 20 of 2016 on Marks; Act No. 30 of 2000 on Trade Secrets; Act No. 31 of 2000 on Industrial Design; and Act No. 32 of 2000 on Layout Design of Integrated Circuit in fact has not accommodate protection against traditional knowledge. Instead of providing benefits for Indonesia, the laws and regulations related to such IPR are considered more favorable to the position of developed states (Saleh, 2010).

In this regard, the need to establish national regulations on the protection of traditional knowledge is urgent. The problem is how to form regulation that can provide benefits and welfare for the people of Indonesia, especially the local community owner of traditional knowledge? This paper is about to contribute suggestions regarding the existence of international law in the establishment of Indonesian national regulations on the protection of traditional knowledge. Therefore, this article will discuss the protection of traditional knowledge in international legal instruments and the existence of international law in the formation of traditional knowledge arrangements in Indonesia

\section{Methodology}

This study designed as doctrinal legal research. Under the characteristics of doctrinal legal research, the data used in this study is secondary data by searching data through studies of primary legal materials, secondary legal materials, and tertiary legal materials. 
The steps taken in this study are: first, collecting legal materials, both primary legal materials, secondary legal materials, and tertiary legal materials, through literature studies. After the materials are collected, they are studied carefully so that the meaning and essence contained in them are in the form of ideas, proposals and arguments and related provisions. All results of research obtained from legal materials then discussed by drafting concepts, principles, and legal provisions. Next look for their relationship with each other using deduction and induction reasoning which is commonly used in legal reasoning to produce propositions and concepts that are either in the form of definition, prescription or classification as a result of research. Furthermore, the existing legal materials are analyzed qualitatively to subsequently draw conclusions that answer the problems discussed while giving prescriptions based on the arguments that have been built in conclusions.

\section{Analysis and Results}

\section{Protection of Traditional Knowledge in International Law Instruments}

Admittedly or not, the current international system of IPR protection is a system whose formation is motivated by the emergence of industrialization in western states and then developed according to the needs of technologically advanced societies. To that end, in recent years, local communities and governments of developing states, in particular, have called for a protection system similar to that applied to IPR for traditional knowledge.

In 2000 WIPO members formed the Inter-Governmental Committee on Intellectual Property and Genetic Resources, Traditional Knowledge and Folklore (IGC), and in 2009 they agreed to develop an international legal instrument that could provide adequate protection for Traditional Knowledge, Genetic Resources and Traditional Cultural Expressions (Folklore). An instrument that can be recommended to WIPO members as a formal agreement that will bind the states that ratified (Directorate of Public Diplomacy Ministry of Foreign Affairs Republic of Indonesia, 2012). This instrument itself has not been agreed upon regarding the differences of views of developed and developing states on the concept of protection of traditional knowledge as described previously.

In the view of developing states, traditional knowledge as part of IPR must be protected, without discrimination, as TRIP's protects seven types of IPR oriented to the interests of developed states. Developing states also see that in practice, the traditional knowledge they have had so far been exploited commercially by the developed states without being accompanied by proper remuneration for their side. Meanwhile, according to developed states, the problem of traditional knowledge has been accommodated in the geographical indication regime. Additionally, the protection of traditional knowledge is not necessary because it has become public domain and the modernization process of local and traditional societies are considered to be adequate compensation for the utilization of IPR (Saleh, 2010). 
Previously, local communities or indigenous people from various states have submitted several statements in some international declarations such as the Manila Declaration on the World Declaration for Cultural Development (1988); Kari-Oca Declaration (1992); Mataatua Declaration (1993); and the Beijing Declaration on Women of Indigenous People. Local communities or indigenous people statements were also raised in the Amazon Valley Indigenous Peoples Coordinating Body (1994); and the South Pacific Regional Consultation on IPR of Indigenous Peoples (1995) (Hakim, 2009).

The absence of an international treaty explicitly regulating the protection of traditional knowledge does not mean that there is no protection against it at all. It is a fact that on the international level, the protection of general knowledge is getting more attention and support. Such concern and support include matters relating to respect for the cultural and spiritual values of traditional knowledge, biodiversity preservation, recognition of social and economic benefits, fairness and equity in the sharing of economic benefits from the utilization of traditional knowledge (Xiong, 2008).

That attention and support have led to the establishment of several international legal instruments that recognize and protect the rights of indigenous peoples or local communities to enjoy their cultural heritage (including traditional knowledge). Some of the examples are the Universal Declaration of Human Rights, the International Covenant on Civil and Political Rights (ICCPR), and the International Covenant on Economic, Social and Cultural Rights (ICESCR). In Article 15 paragraph (3) of ICESCR, it states that:

"The states Parties to the present Covenant recognize the right of everyone to benefit from the protection of the moral and material interests resulting from any scientific, literary or artistic production of which he is the author."

Explicit arrangements on the protection of traditional knowledge, especially those related to genetic resources can be found in the 2010 Nagoya Protocol on Access to Biological Resources and Equitable and Equitable Benefits Distribution of Utilization. Article 3 of the Protocol stated that:

"This Protocol shall apply to genetic resources within the scope of Article 15 of the Convention and the benefits arising from the utilization of such resources. This Protocol shall also apply to traditional knowledge associated with genetic resources within the scope of the Convention and to the benefits arising from the utilization of such knowledge."

The Convention on Biological Diversity (CBD), particularly in Article 8 letter j, states that participating states shall respect, preserve and maintain traditional knowledge; in using it should seek approval from and engage its holders, and should seek for a fair distribution of benefits from its use. Furthermore, in May 2002, the participating States of the CBD made the Bonn Guidelines on Access to Genetic Resources and Fair and Equalization of Arising Out of Their Utilization, fundamentally "encouraging" the 
disclosure of the state of origin of genetic resources and traditional knowledge in any patent application (Hawin, 2009).

Bonn Guidelines itself has its disadvantages because it is merely "encouraging" the protection of traditional knowledge. CBD itself entirely entrusted to the participating states to determine how the implementation of such commitments. Therefore, without the support of international IPR deal, the commitment is difficult to implement (Hawin, 2009).

\section{International Law in the Establishment of Traditional Knowledge Regulations in Indonesia}

In the context of international relations today, international treaties are the most important source of international law. It seems that almost all the results of international relations are poured in the form of international treaties that formulate the rights and obligations of the parties in the relationship. According to Purwanto (2009):

"... during the ongoing relationships between states or international relations, during which it will also create international treaties. Through international treaties, the implementation of the rights and obligations of the as members of the international community will be more directed and guaranteed."

In the formation of a treaty, each has equal status. It reinforced by the principle of "pacta sunt servanda," which allows each to have equality in the formation of the agreement.

The reality that is happening today, the will to build inter-cooperation has been shown by the international community, as a step to fulfill their interests with the help of other states. Therefore, it is only natural that the inter-cooperation is directed to meeting the needs and interests of the international community in achieving its objectives.

The function of international law in the context of legal knowledge is often understood only as a rule or rule applicable to the subject, but it is only one of the various functions of international law. Other functions that are less attention by the legal knowledge include as a political instrument used by the government of a state to achieve its national goals. According to Hikmahanto Juwana (2010):

"The existence of international law that serves as a political instrument is based on the reality of relations between states that can not be separated from the interests of each other. Moreover, in the global era where the physical boundaries seem to be absent (borderless). The problems faced by a state will be tangent to the sovereignty of other states, such as the problem of international trade, the fight against terrorism, environmental issues, and human rights issues. "

As a member of the WTO, Indonesia is bound by WTO provisions in its national legislation, including those related to TRIP's. Indonesia has done it with the enactment of several laws relating to IPR such as the Law on Copyrights, Patents, 
Trademarks, Trade Secrets, Industrial Designs and Layout Designs of Integrated Circuits. However, the law has not yet accommodated the protection of traditional knowledge.

Hawin (2009) proposes two steps to address the need for Indonesian national regulations that protect traditional knowledge: first, improving legislation in the field of IPR by affirming the protection of local knowledge. For example, in the Law on Patents should be required the mention of traditional knowledge used in the invention petitioned for patent and ask permission to the holder of traditional knowledge. Additionally, the Law on Patents must affirm that traditional knowledge is prior art that can dispel a patent application, may even be used as a reason to cancel the patent.

The second step is that Indonesia can create a separate law (suigeneris) on traditional knowledge used as an umbrella rule. This law should provide a firm understanding of traditional knowledge, its legal protection, including the way of its registration, the body that will handle traditional knowledge, and others. It is also necessary to regulate the procedures and requirements of transferring traditional knowledge (Hawin, 2009). In line with that, matters relating to the problem of foreigners access to traditional Indonesian knowledge, the sharing of benefits to local communities over access and use of traditional knowledge is also essential to regulate in the law (Rosidawati, 2013).

For achieving this point, the government needs to do an inventory and documentation to create a database of work or knowledge that will be categorized as traditional knowledge. This step is vital to clarify what will be protected, preserve traditional knowledge, and prevent it from extinction and simultaneously show the government's seriousness to protect traditional knowledge (Kusumadara, 2011). Inventory is included in the defensive protection step defensive. By doing defensive protection minimizes the occurrence of abuse against the law against the traditional culture of a society. Steps are carried out by various countries and the community in making positive use this protection is by building databases related to traditional culture in the country concerned (Hutabarat, 2015). The protection through defensive mechanism will assure unlimited use of traditional knowledge for its indigenous people group as its owner. This protection method could be manifested by registering and documenting the existing traditional knowledge. A particular defensive protection form has been a part of the Intellectual Property system for a long time (Kurnilasari, Yahanan, \& Rahim, 2018).

Related to the development of the sui generis system in the protection of traditional knowledge in Indonesia, Rosidawati (2013) stated that:

"Indonesia can consider the sui generis system considering the characteristics of Indonesian society that are very different from western society. Characteristics of Indonesian society are still affected by collective or communal and religious systems so that the behavior of the community is still impregnated and guided by 
the value system. Thus, creating a law based on a different value system will only cause problems in its implementation."

Improvement of legislation in the field of IPR and the establishment of laws that specifically regulate local knowledge protection will not effectively work if it is not supported by international agreements. It related to the open possibility of traditional knowledge of Indonesia can still be taken by other countries that do not recognize the traditional knowledge of other states (Hawin, 2009). Therefore, Indonesia also needs to be active to follow the steps of other developing countries in proposing TRIP's improvements to protect traditional knowledge.

The active involvement of Indonesia in promoting TRIP's improvements could make it easier for Indonesia to encourage its national interests in new international agreements. In that connection, Indonesia can morally assure that there are important reasons for protecting traditional knowledge. As Erstling (2009) says, “... those communities should have the right to make use of their Traditional Knowledge under their customs and policies, free from misappropriation or misuse by others."

Indonesia can also fight for its interests through regional cooperation forums, especially ASEAN. According to Kariyawasam and Guy (2008), strengthening regional cooperation in terms of protection of traditional knowledge is a very effective strategy to achieve what is the goal of a state. Furthermore said by Kariyawasam and Guy (2008):

"Regional experiences should be encouraged and supported, which would make it easier to find a comprehensive, holistic system when joint processes are initiated. It is suggested here that a regional regime would optimize the possibility for cooperation among the Members to manage biodiversity; to maximize the efficient use of resources, and to ensure that the benefits from their exploitation are fairly and equitably shared in the region ... Although protection of indigenous knowledge has become the particular property of sovereign states, this issue has gained momentum in a more generalized (supra-national) regional context."

In the context of ASEAN itself, on February 24, 2000, has been agreed on the draft of the ASEAN Framework Agreement on Access to Biological and Genetic Resources. This Agreement recognizes, respects, maintains and retains the knowledge, innovations, and customs of indigenous peoples in carrying out their traditional life, including their genetic resources. One of the objectives of the agreement is to protect traditional knowledge from indigenous peoples and to facilitate appropriate remuneration or benefit-sharing for indigenous peoples in terms of their traditional knowledge used by others.

In this regard, through the ASEAN forum, Indonesia can further encourage the ratification and enforcement of the ASEAN Framework Agreement on Access to Biological and Genetic Resources for ASEAN member states. 
Simultaneously, Indonesia must also "select" on some international legal instruments relating to the protection of traditional knowledge in harmony with Indonesia's national interests. Instruments that benefit the national interest must be immediately ratified or followed by Indonesia, with or without a reservation. Furthermore, as a consequence of the practice of Indonesia which is more inclined to monism with the primacy of international law (Kusumaatmadja, 1999), these favorable provisions are adopted in the national regulations to be established.

\section{Conclusion}

To establish special arrangements regarding traditional knowledge that can provide benefits and welfare to the community, especially local communities or indigenous people as owners of traditional knowledge owners, Indonesia must be observant in adopting many international legal instruments related to this issue. Also, ensure that the binding of these international legal instruments following Indonesia's national interests.

The absence of an international legal instrument specifically regulating the protection of traditional knowledge should not cause Indonesia to delay the formation of a national regulation related to it. The establishment of the national regulation can be used as the momentum of Indonesia to take action to encourage the achievement of international agreements on the protection of traditional knowledge that has a positive impact on Indonesia.

Regional cooperation forums, mainly ASEAN, can also be an effective means for Indonesia in its fight for its importance on the protection of traditional knowledge. Indonesia should encourage existing agreements within the ASEAN regional level to be implemented by ASEAN member states.

\section{References}

Directorate of the Public Diplomacy Ministry of Foreign Affairs Republic of Indonesia. (2012). 56 Year V. Tabloid Diplomasi.

Erstling, J. (2009). Using Patents to Protect Traditional Knowledge. Texas Wesleyan Law Review, 295(651), 295-333.

Hakim, L. (2009). Upaya Harmonisasi Hukum Terhadap Perlindungan Pengetahuan Tradisional (Traditional Knowledge) di Indonesia. Jurnal Yustika, 12(2), 171182.

Hawin, M. (2009). Perlindungan Pengetahuan Tradisional di Indonesia (No. August 5, 2009). Yogyakarta.

Hutabarat, S. M. D. (2015). Perkembangan dan Perlindungan Pengetahuan Tradisional dan Ekspresi Budaya Tradisional Ditinjau dari Perspektif Hak Kekayaan Interlektual. Jurnal Yuridis, 2(2).

Juwana, H. (2010). Hukum Internasional Dalam Perspektif Indonesia Sebagai Negara Berkembang. Jakarta: Yarsif Watampone.

Kariyawasam, K., \& Guy, S. (2008). Intellectual Property Protection of Indigenous Knowledge: Implementing Initiatives at National and Regional Levels. Deakin Law Review, 12(2).

Kurnilasari, D. T., Yahanan, A., \& Rahim, R. A. (2018). Indonesia's Traditional 
Jurnal Hukum

Novelty

Volume 10, Issue 01, 2019, pp. 01-10

P-ISSN: 1412-6834

E-ISSN: 2550-0090

Knowledge Documentation in Intellectual Property Rights' Perspective. Sriwijaya Law Review, 2(1), 110.

Kusumaatmadja, M. (1999). Pengantar Hukum Internasional. Putra A. Badin.

Kusumadara, A. (2011). Pemeliharaan dan Pelestarian Pengetahuan Tradisional dan Ekspresi Budaya Tradisional Indonesia: Perlindungan Hak Kekayaan Intelektual dan Non-Hak Kekayaan Intelektual. JURNAL HUKUM IUS QUIA IUSTUM, 18(1),

Oguamanam, C. (2004). Localizing Intellectual Property in the Globalization Epoch: The Integration of Indigenous Knowledge. Indiana Journal of Global Legal Studies, 11(2), 135. https://doi.org/10.2979/gls.2004.11.2.135

Oseitutu, J. J. (2013). A Sui Generis Regime for Traditional Knowledge: The Cultural Divide in Intellectual Property Law. Marquette Intellectual Property Law Review, 15(1). Retrieved from http://ssrn.com/abstract=1574996

Purwanto, H. (2009). Keberadaan Asas Pacta Sunt Servanda dalam Perjanjian Internasional. Mimbar Hukum, 21(1), 155-170.

Rosidawati, I. (2013). Konsep Perlindungan Pengetahuan Tradisional Berdasarkan Asas Keadilan Melalui Sui Generis Intellectual Property System. JURNAL HUKUM IUS QUIA IUSTUM, 20(2), 163-185.

Saleh, G. (2010). Upaya Perlindungan Hukum bagi Pengetahuan Tradisional di Negara-Negara Berkembang Khususnya Indonesia. Jurnal Supremasi Hukum, $3(1)$.

Sardjono, A. (2010). Hak Kekayaan Intelektual dan Pengetahuan Tradisional. Bandung: Alumni.

The Secretariat of WIPO. (2002). TRADITIONAL KNOWLEDGE - OPERATIONAL TERMS AND DEFINITIONS (No. WIPO/GRTKF/IC/3/9). Retrieved from https://www.wipo.int/edocs/mdocs/tk/en/wipo_grtkf_ic_3/wipo_grtkf_ic_3_9 .pdf

Xiong, P. (2008). Traditional Knowledge and Intellectual Property Protection - the Endeavour of Niue. Revue Juridique Polynesienne, 13, 496-498. Retrieved from http://ssrn.com/abstract $=2476725$ 